\title{
Evolutionary Analysis of Tax Law: A Methodological Approach
}

\author{
Ute Schmiel \\ Chair of Business Taxation, University of Duisburg-Essen, Essen, Germany \\ Email: Ute.Schmiel@uni-due.de
}

Received 15 February 2016; accepted 9 April 2016; published 12 April 2016

Copyright (C) 2016 by author and Scientific Research Publishing Inc.

This work is licensed under the Creative Commons Attribution International License (CC BY). http://creativecommons.org/licenses/by/4.0/

(c) (;) Open Access

\section{Abstract}

The present paper conceptualizes a methodology of an evolutionary tax law analysis from a critical rationalist perspective. This methodology has the following characteristics: We interpret tax rules as means to achieve tax goals. Means-end-statements have an ethical and an empirical dimension. The ethical dimension implies that tax goals and tax rules and their secondary effects must be compatible with the aims of market economy regulation. The empirical dimension includes the question if tax goals are realizable and if tax rules cause secondary effects. To answer this question, we need evolutionary hypotheses of tax effects. A quasi-nomological hypothesis regarding the evolutionary effects of taxation is as follows: "If taxation changes the rank order of the relevant decision-making options according to the actors' subjectively rational decision criteria, they decide differently if they take taxes into account than they would if they did not". From an evolutionary point of view, freedom of choice and equality before the law are the contributions of a market economy to the common good. In our opinion, equability of taxation is compatible with the market economy goals "freedom of choice" and "equality before the law". Equability of taxation, however, implies in principle decreasing such decision-making effects of taxation which reduce the explicit tax payment burden (in relative terms). These decision-making effects are designated here as tax avoidance decisions. We need the evolutionary tax effects framework mentioned above in order to develop tax rules which decrease such tax effects. By way of contrast, tax rules that induce or accept tax avoidance decisions conflict with equability of taxation. Such rules are sometimes driven by social goals. Thus, we have to analyze such rules from an evolutionary perspective with regard to their justification, feasibility and proportionality.

\section{Keywords}

Equability of Taxation, Economic Analysis of Tax Law, Evolutionary Hypotheses of Tax Effects 


\section{Introduction}

The object of economic tax law analysis is the question of how to design adequate tax rules. Adequate tax rules means that rules are compatible with market economy goals and consider hypotheses of tax effects. An evolutionary analysis of tax law asks if tax rules are compatible with evolutionary market economy goals and if they consider evolutionary hypotheses of tax effects. The present paper develops a methodology of an evolutionary economic tax law analysis from a critical-rational perspective according to Hans Albert [1] and Volker Gadenne [2]. The paper focuses on an evolutionary tax law analysis which refers back to hypotheses regarding tax effects on financial decisions. Further consequences of taxation, such as distribution or revenues, and other (non-financial) tax effects are not excluded from economic tax law analysis. They are not, however, subject of the present paper.

Considerations regarding such an evolutionary analysis of tax law have not been developed in any detail thus far. In terms of content, evolutionary analysis of tax law can be seen as part of the economic analysis of law. Nevertheless, the relevant works which can be aligned to economic analysis of law do not have an evolutionary basis [3]. Although evolutionary analysis of tax law also forms part of an evolutionary economic policy, the approaches presented here do not relate to taxation [4] [5]. In addition, evolutionary analysis of tax law is a component of tax research. Dieter Schneider and Rainer Elschen have taken evolutionary taxation goals into account in earlier publications. They postulated the avoidance of "proven, case-related decision distortions" ([6], p. 103, translation by the author) or the avoidance of "externally observable decision-making influences" ([7], p. 351, translation by the author) [8]. However they did not discuss the theoretical integration of these effects. In addition, despite the fact that numerous studies have presented effects of taxation based on investigations of theoretical models [9]-[11] and on empirical studies [9] [12]-[14], an evolutionary tax effects theory has as yet been missing. We will point out that from a critical rationalist view, the evolutionary analysis of tax law needs such a theoretical framework. It is necessary because we interpret tax rules as means to achieve tax goals. In consequence, we need a theoretical framework in order to analyze if tax rules can achieve these goals and if they cause secondary effects. However, in a critical rationalist view, it is not sufficient to merely transform a scientific explanation into a means-ends-statement but rather it is necessary to support means and ends by arguments. From an evolutionary point of view, we have to ask if tax goals are compatible with evolutionary market economy goals. In consequence, our paper has two parts. Firstly, we develop an evolutionary tax effects framework. Secondly, we examine if the tax goal of avoiding tax effects which is often postulated in tax research [15]-[17] is consistent with evolutionary market economy goals. For this, we will first interpret evolutionary market economy goals based on the interpretation of a market economy by Victor Vanberg. Furthermore, taking the evolutionary hypotheses of tax effects into account, we will ask if this tax goal is realizable.

In order to respond the research question of the present paper- - How can we conceptualize an evolutionary analysis of tax law which refers back to evolutionary hypotheses on financial effects of taxation from a critical rationalist perspective?"- the reminder of the paper is organized as follows. We will begin by outlining this critical rationalist methodology in Chapter 2. Chapter 3 will deal with evolutionary hypotheses of (financial) tax effects, and Chapter 4 will examine whether the tax goal of avoiding tax effects is compatible with evolutionary market economy goals and whether it is realizable. Chapter 5 summarizes the results and addresses arguments which support an evolutionary analysis of tax law as developed here.

\section{Analysis of Tax Law from a Critical Rationalist Perspective}

The research question of this paper is: "How can we conceptualize an evolutionary analysis of tax law which refers back to evolutionary hypotheses on financial effects of taxation from a critical rationalist perspective?” We will give an answer here in terms of a critical rationalism based on Hans Albert and Volker Gadenne [1] [2]. In the light of a critical-rationalist perspective, tax rules are means to achieve tax goals. In accordance with this perspective, we adopt the postulate of freedom from value judgment of Hans Albert [18]. This states that proposals for tax rules should be developed as alternatives to other proposals and have to be supported by argument. The policy recommendations and arguments have to be presented for critical discussion [18]. This implies furthermore that ends must be set as a hypothetical basis because from a critical rationalist perspective, neither ultimate nor undisputable means nor ultimate and undisputable goals exist. In addition, ends do not justify the means. In terms of content, economic analysis of tax law is not subjected to any restrictions through the perspective of freedom from value judgment as long as these critical rational "basic rules" are followed [19]. 
From a critical rationalist view, means-end-statements have an ethical and an empirical dimension. The ethical dimension implies that tax goals and tax rules as well as their secondary effects must be compatible with the aims of market economy regulation because the tax system is part of economic regulation [20]. For this reason, the substantiation of tax objectives first needs a clear idea of the aims that market economy regulation (and therefore also the tax system) is supposed to fulfill. The empirical dimension of means-end-statements results from the postulate that ought implies can [18] as well as from the fact that it is necessary to recognize also the secondary effects of tax rules in order to analyze them in an ethical perspective.

Ought implies can means that it is not sufficient to stipulate that market economy regulation ought to fulfill certain (hypothetically set) goals. It is also necessary that market economy regulation can meet these objectives. The aims of market economy regulation and therefore also of tax objectives must be realizable. The feasibility of tax aims and the analysis of secondary effects of tax rules require hypotheses based on empirical science. Whether the aims of market economy regulation are realizable in general terms and therefore whether substantiation of tax goals in particular is feasible depends on factors such as the actions of individuals and companies and the way in which markets function. Similarly, the examination of tax rules regarding their secondary effects depends on these factors. This means that we require empirical science hypotheses on the actions of individuals and companies and furthermore hypotheses on the functionality of markets. We also need to take into account that taxes themselves influence economic activity and the way in which markets work. By decreasing income, or profits and assets, and by intervening in the decisions of individuals and companies, taxes create decision-making effects. Decision-making effects imply that a decision made after taking taxes into account deviates from the original decision taken without consideration of taxes. A tax effect would, for example, be in evidence if, after considering taxes, a different decision is made regarding an investment, financing, or a choice of legal form than without this consideration [6] [11] [14] [17].

Hypotheses on the effects of taxes have to meet critical rationalist requirements. In the case of the explanation, the result that needs to be explained is known. We need assumptions and quasi-nomological hypotheses from which we can deduce the result we want to explain. In the case of the prediction, on the other hand, the focus is on deducing the expected outcome from the known assumptions and the relevant quasi-nomological hypotheses. We use the term "quasi-nomological hypotheses" because the question whether (economic) law exists will not be considered further. According to the view presented here, it is reasonable to assume that there are at least regularities in economic facts and circumstances. Alongside further conditions relating to adequacy, a scientific explanation or prediction requires assumptions and quasi-nomological hypotheses to be empirically confirmed [21]. However, in consequence of the induction problem, we can never regard hypotheses as finally verified [2] [18]. Furthermore, we take critical realism as a basis [1]. Observation within the scientific context is, therefore, always theory-laden [22]. One consequence is that a hypothesis cannot be finally falsified. For this reason, the postulate of "empirical truth" is understood in such a way that empirical hypotheses have to be critically tested and that any contradictions which emerge have to be taken into account [2]. On the basis of this critical rationalist explanation model, the type of explanation model put forward by Milton Friedman is rejected. In the case of the latter, the adequacy of statements is judged (exclusively) by the validity of the prediction. This means that the focus is not on the empirical truth of assumptions. It is sufficient that the correlations of the theoretical model are confirmed within the scope of empirical investigations [3] [23]. From a critical rationalist point of view, it is not sufficient to measure correlations [24]. The question is rather whether it is possible to explain these correlations in a scientific manner. Equally little account is taken of Dieter Schneider's view that, in measuring tax effects, lower requirements are made on the truth of assumptions as no policy recommendations are derived from them [6] [11]. The view represented here is that the use of such a measurement theory remains open.

\section{An Evolutionary Framework of Tax Effects on Financial Decisions}

Chapter 2 shows that from a critical rationalist view, the evolutionary analysis of tax law requires a theoretical framework. As we interpret tax rules as means to achieve tax ends, we need to know if tax rules can achieve tax goals and if tax rules cause secondary effects. Furthermore, tax effects hypotheses have to fulfill the critical rationalist requirements.

In tax research, numerous investigations into tax effects based on theoretical models are available [9]-[11]. We can also find many empirical studies [9] [12]-[14]. However, there is no tax effects theory consisting of a quasi-nomological hypothesis on tax effects which links or delineates the individual hypotheses. When Han- 
lon/Heitzman ([9], p. 168) postulate an "overall theory or framework to direct our research effort”, they think along similar lines.

Hypotheses based on theoretical models often have recourse to neoclassical action hypotheses, into which taxes are integrated [9]-[11] [25]. Although Scholes et al. speak of a "planning approach", this is addressed to "social planners" too ([26], p. 9). The neoclassical hypothesis or (simplifying) assumption is that individuals will maximize their financial utility (in the form of consumption, income or assets) if they take taxes into account [17] [27]. Individuals act in a perfectly rational manner, i.e. they act consistently and have perfect and objectively appropriate knowledge of the world [28] [29]. This complete knowledge is the result of the market conditions assumed in the model of a perfect capital market in a neoclassical general equilibrium framework. According to the neoclassical view, the interplay of supply and demand on such a market leads to the formation of market-clearing equilibrium prices [30]. In order to maximize their financial utility, individuals follow perfectly rational decision criteria; in a world based on conditions of certainty, the net present value is e.g. such a perfectly rational decision criterion. If individuals generate their financial utility as company owners, then the perfectly rational decision criteria of the company and of the shareholders are identical [17] [27].

Since tax payers include taxation within their calculation, effects occur if taxation changes the rank order of the relevant decision-making options according to the actors' perfectly rational decision criteria. A quasi-nomological hypothesis would be as follows: "If taxation changes the rank order of the relevant decision-making options according to the actors' perfectly rational decision criteria, they decide differently if they take taxes into account than they would if they did not” (similar to [31]). Effects of taxation are caused by differences in taxation. Differences in taxation result from different definitions of tax bases, e.g. differences in the definition of taxable income and/or different tax rates. In the case of taxes that fall due periodically, differences in the tax bases may have their foundation in different definitions of the tax base and/or in different definitions of timing. Tax base differences are differences in the tax base before consideration of interest effects, which may be caused by aspects such as different tax exemptions of cash inflows or differences in the tax deductibility of cash outflows. Differences in timing are caused by the fact that accounting on a cash-basis applies to some facts and circumstances, whereas others are governed by assessment based on balance sheet accounting [17].

In accordance with a critical rationalist understanding of explanation and prediction, the explanation would be as follows. The event to be explained would be: "In a specific decision-making situation, actors who take taxes into account decide differently than they would if they did not". This is deduced from the quasi-nomological hypothesis: "If taxation changes the rank order of the relevant decision-making options according to the actors' perfectly rational decision criteria, they decide differently if they take taxes into account than they would if they did not" and from the assumption "In a specific decision-making situation, taxation under prevailing law changes the rank order of the relevant decision options according to the actors' perfectly rational decision criteria". In the case of a prediction, the expected event would be deduced from the assumption that "In a specific decision-making situation, taxation under prevailing law changes the rank order of the relevant decision-making options according to the actors' perfectly rational decision criteria" and the appropriate quasi-nomological hypothesis "If taxation changes the rank order of the relevant decision-making options according to the actors' perfectly rational decision criteria, they decide differently if they take taxes into account than they would if they did not". In consequence we can deduce: "In a specific decision-making situation, actors who take taxes into account decide differently than they would if they did not".

Empirical studies based on capital markets data confirm the existence of tax effects. Taking neoclassical tax effects models as a basis, these studies test the extent to which such theoretical tax effects models can be found in reality. Effects of this nature are illustrated in numerous studies [13] [14]. According to the critical rationalist understanding of explanation and prediction adopted here, however, neoclassical hypotheses of tax effects cannot explain these tax effects. In line with a critical rationalist understanding of explanation, the assumptions and the quasi-nomological hypothesis would need to be empirically confirmed [21]. Inter alia, this would require individuals to act in a perfectly rational manner.

However, perfectly rational action requires complete knowledge of the world [28] [29]. This is contradicted by the evolutionary action hypothesis that individuals have only incomplete knowledge and are aware of this fact. One reason for incomplete knowledge is the large number of possible action options. Nevertheless, the incompleteness of knowledge extends beyond so-called stochastic uncertainty. Stochastic uncertainty means that individuals are able to assign objective probabilities to possible states of nature. Incomplete knowledge also exists because the quantity of possible action options is not fixed at the time when the decision is made [32] [33]. 
For this reason, although individuals can act consistently, they can only act in accordance with their subjective knowledge. This internal consistency of preferences and theories guiding action is designated here as subjective rationality [28] [31] [34] [35].

Perfect rationality contradicts reality insofar as it is considered to be realistic that unforeseen circumstances can arise which will be unknown to the individuals at the time when the decision is made [34]-[39]. This is also indicated by empirical facts and circumstances which cannot be explained without contradiction with the assumption of stochastic uncertainty. If, for example, the set of possible actions at the time of decision was already fixed within the meaning of stochastic uncertainty, innovations would be impossible [32] [40]. This objection that empirical facts and circumstances cannot be explained without contradiction applies especially if certainty or stochastic uncertainty is linked with perfect markets. The particular problem regarding a perfect (capital) market with choice under certainty or stochastic uncertainty is that empirical facts and circumstances such as absolute scarcity of resources, economic illiquidity, state activity and the necessity of imposing taxes can only be explained in a world where there is genuine uncertainty [5]. Such empirical facts and circumstances, which are not defined in perfect markets with choice under certainty or stochastic uncertainty, can only be integrated into perfect markets in a contradictory manner in the form of so-called "hybrid models". These combine contradictory assumptions of the real world with those of the neoclassical world [31] [41], with the consequence that any statement may be inferred [18].

Perfect rationality is also questioned through (predominantly experimental) studies of tax effects oriented towards behavioral science. These studies investigate for instance whether participants choose perfectly rational decision criteria or whether they have the necessary knowledge to be able to apply perfectly rational decision criteria. These studies generally prove that the neoclassical rational model of consumption maximization cannot be empirically supported because the actual consideration of taxes in decisions often deviates from this model [12] [42]-[44]. The question arises whether evolutionary quasi-nomological hypotheses of tax effects avoid contradictions with reality and also consistently connect these research results of empirical studies. In order to develop evolutionary hypotheses, we now use neoclassical hypotheses as a theoretical layer [45]. For reasons of simplification we restrict these initial considerations regarding an evolutionary tax effects theory to hypotheses of tax effects regarding yields. Effects based on liquidity are not considered, despite the fact that liquidity influences decisions of individuals beyond a perfect capital market.

It is a constituent element of evolutionary theories [32] [40] that unforeseen circumstances arise [34]-[39]. Given this genuine uncertainty [5], evolutionary theory states that no perfect markets with a general competitive equilibrium exist [30] [33] [35] [38]. If there is genuine uncertainty, as has already been emphasized, an evolutionary hypothesis states that, although individuals may operate consistently, they are only able to act in accordance with their subjective knowledge of the world and thus in a subjectively rational manner [28] [31] [34] [35]. The main function of the evolutionary market is to coordinate interests. The central hypothesis, which was already presented by Adam Smith [46], is that individuals who act in their own interest adapt their actions to the interests of other actors [40] [47] [48]. Indeed, we have to consider that actors differ regarding their resource power [49] so that we have to expect that they primarily adapt their actions to the interests of powerful actors.

According to Gerhard Wegner [45], individuals acting under genuine uncertainty are able to maximize their subjectively probable expectations of utility whilst taking into account that taxes may change probable expectations of (financial) utility. Whether expectations of utility are fulfilled, however, is "genuinely uncertain”. In the case of genuine uncertainty, no perfectly rational decision criteria exist. There are only subjectively rational decision criteria. Like any other decision criteria, net present value is not a perfectly rational decision criterion. For some individuals, however, it may be a subjectively rational decision criterion. Since no perfectly rational decision criteria exist in cases of genuine uncertainty, it is conceivably, although in no way inevitably subjectively rational that individuals will follow net present value as a super ordinate decision criterion and compatible criteria derived from this for downstream decisions. Furthermore, from a perspective of methodological individualism it is questionable whether the criteria used for decisions in companies are always identical with the decision criteria of the company owner. At least in the case of public companies which have an executive board, the expectation is that company actions are caused by the action of individuals but that such organized action of individuals will deviate from separate action by individuals [50]. Therefore we need an evolutionary theory of the firm in order to hypothesize tax effects regarding firms.

Tax effects depend on the decision criteria individually used. An evolutionary quasi-nomological hypothesis would therefore be as follows: "If taxation changes the rank order of the relevant decision-making options ac- 
cording to the actors' subjectively rational decision criteria, they decide differently if they take taxes into account than they would if they did not” (similar to [31]). Subjectively rational decision criteria may be net present value (or compatible criteria derived from this for downstream decisions) or also a simpler heuristic (in comparison to the net present value). If individuals or companies follow net present value, they set a criterion that would be perfectly rational under neoclassical model conditions. This is, however, not because the neoclassical model conditions are met but because, given genuine uncertainty, it is subjectively rational for these individuals or companies to set this as a heuristic. The fact that individuals or companies sometimes use this criterion may be due to scientific tax planning recommendations (the "consultancy influence” [51]). If tax planning recommendations are based on neoclassical model conditions and if tax payers avail themselves of these recommendations, individuals and companies will be acting as in the neoclassical model and effects will occur that correspond to the neoclassical theory of tax effects. In an evolutionary tax effects theory, the focus is on hypotheses of how taxes affect the decisions of individuals and companies if they act under genuine uncertainty and if they set a neoclassical criterion as a heuristic on imperfect markets (for differentiated treatment of the performativity of markets, see [52] [53]).

The reasons for effects of decisions depend on the criteria used. Differences in the definition of the tax base (except differences in the definition of timing) and tax rate differences are reflected both in static and multi-period criteria (albeit to a different extent). Differences in the definition of timing are only covered in multi-period decision criteria. The answer to the question whether there are differences in the definition of the tax base and in the tax rate is theory-laden. It depends, for example, on the theory of the firm used with regard to the question of whether tax differences relate to the company or to the company owner.

In contrast to neoclassical quasi-nomological hypotheses regarding tax effects, evolutionary quasi-nomological hypotheses of tax effects can explain the results of empirical studies. The results of numerous studies show that effects occur in public companies because of taxation [9] [13] [20]. These effects can be explained by the evolutionary quasi-nomological hypothesis of tax effects "If taxation changes the rank order of the relevant decision-making options according to the actors' subjectively rational decision criteria, they decide differently if they take taxes into account than they would if they did not" and by the assumption "In a specific decisionmaking situation, taxation under prevailing law changes the rank order of the relevant decision options according to the actors' subjective decision criteria”.

One of the reasons why empirical studies show tax effects may be the fact that empirical studies conducted on the basis of capital market data predominantly relate to differences in the definition of tax base or differences in the tax rate, which in turn are covered by virtually any subjective criterion (albeit to a different extent). It is also conceivable that the companies considered use a net present value or compatible criteria derived from this as a heuristic or even that this criterion functions as a myth [54]. A net present value reflects differences in timing, tax base and tax rates. In this case, tax effects will occur that correspond to the neoclassical theory of tax effects.

Experimental studies oriented towards behavioral science relate to the actions of natural persons. They confirm, as has already become clear, that the actual consideration of taxes in decisions often deviates from the neoclassical model of consumption maximization [12] [42]-[44]. In order to explain these deviations, we need hypotheses which substantiate the quasi-nomological hypothesis regarding tax effects. One conceivable hypothesis is that, in the case of decisions regarding taxation (as compared to net present value), it may be subjectively rational for individuals to use simpler heuristics or, in accordance with the hypothesis of Prospect Theory [55]-[57], for individuals to evaluate decision options in respect of their changes to a reference status [42] [44].

Evolutionary analysis of tax law requires hypotheses of tax effects. We present such a theoretical framework which implies the following quasi-nomological hypothesis of tax effects: "If taxation changes the rank order of the relevant decision-making options according to the actors' subjectively rational decision criteria, they decide differently if they take taxes into account than they would if they did not”.

\section{Avoiding Tax Effects as an Adequate Tax Goal?}

Chapter 2 defined critical rationalist requirements of taxation goals within the scope of economic tax law analysis. Taxation goals (“ends") and tax rules ("means”) must be set as a hypothetical basis. They must be compatible with market economy objectives and tax goals must be realizable. Therefore, the economic analysis of tax law has an ethical and an empirical dimension. Subject of the empirical dimension is the question if tax goals are realizable, and if tax rules cause secondary effects, such as effects on financial decisions. Because of this empir- 
ical dimension, we need tax effects hypotheses among others. The quasi-nomological hypothesis regarding tax effects proposed here is: "If taxation changes the rank order of the relevant decision-making options according to the actors' subjectively rational decision criteria, they decide differently if they take taxes into account than they would if they did not". For the goal "avoidance of tax effects", for example, the means would be to avoid differences in timing, tax base, and tax rates wherever possible. Regarding the goal of "strengthening (certain) tax effects", the policy recommendation would be to induce (certain) differences in timing, tax base, and tax rates. If there is another tax goal, it is important to know if the compatible tax rules cause tax effects on financial decisions. We would have to accept these as secondary effects.

In a critical rationalist view, we must support means and ends by arguments. Subject of the ethical dimension is to analyze if tax goals, tax rules, and their secondary effects are compatible with market economy goals and with other social goals. Certainly, as market economy goals and social goals must be realizable as well, the ethical analysis of market economy goals or social goals has an empirical dimension, too.

We now investigate from an ethical and empirical perspective whether the taxation goal of avoiding tax effects applies evolutionary market economy goals. Thus, we take the aim of avoidance of tax effects as a basis which is postulated in tax research. Avoidance of tax effects is interpreted as neoclassical decision neutrality [15]-[17]. It is postulated in an evolutionary form as evolutionary avoidance of proven decision distortions [6] or evolutionarily justified decision neutrality [7] [20]. However, as we mentioned in Chapter 1, these authors did not discuss a theoretical integration of these effects. Furthermore they use "avoidance of tax effects" as a means to achieve ends which differ from our substantiation of market goals.

Chapter 2 shows that substantiation of tax goals first needs a clear idea of the aims that market economy regulation is supposed to fulfill. How can we describe these aims? The fundamental argument of market economy regulation is that individuals pursue their individual utility and through this indirectly contribute to the common good, "led by an invisible hand" ([58], p. 35, [47]). If we interpret the common good as macro-economic Pareto-efficiency, then Pareto-efficiency can only be achieved within a general competitive equilibrium. Pareto-efficiency requires a decision-neutral taxation. This implies that no tax effects occur within the concept of the neoclassical tax effects theory [15] [16]. As has already become clear in Chapter 3, from the perspective of evolutionary theory, a general competitive equilibrium that implies a maximum of welfare within the concept of Pareto-efficiency is not realizable under genuine uncertainty [30] [35] [38] [48]; contrast [59]. The realization of macro-economic Pareto-efficiency beyond a general competitive equilibrium fails in case of genuine uncertainty because individuals are only able to maximize their (financial) utility expectations. One cannot prevent that individuals suffer losses as a result of their own actions or because of the actions of others [5] [45]. Although from an evolutionary perspective, markets are institutional arrangements via which interests are coordinated, in the case of genuine uncertainty we cannot say that interests are coordinated efficiently [40].

With regard to the problems of measuring welfare [60], it is also not possible to support the assertion that market economy regulation creates more welfare than other forms of the coordination of economic activity without further assumptions. It is, however, possible to argue that in a world with genuine uncertainty, the perfectly rational decision cannot be ascertained [37] [61] and thus the individuals affected know their subjective utility expectation better than a third party. This supports the idea that this expectation is generally realized better when the individuals themselves decide.

This consideration that market economy regulation cannot achieve the maximization of welfare is stated by James M. Buchanan and Viktor Vanberg in the formula "The market economy, as an aggregation, neither maximizes nor minimizes anything". Instead, "It simply allows participants to pursue that which they value, subject to the preferences and endowments of others, and within the constraints of general 'rules of the game' that allow, and provide incentives for, individuals to try out new ways of doing things” ([40], p. 181, italics are in the original text [48] [62]). Based on this consideration, market economy regulation can only achieve freedom of choice and, as we will see below, equality before the law as universal rights. This means that individuals who pursue their individual utility contribute indirectly to the common good in terms of freedom of choice and equality before the law. The reason is that self-interest economic activity as constituent characteristic of market economy regulation requires freedom of choice. At the same time, this freedom of choice places an obligation on the individual. Individuals have the freedom to structure their economic activity themselves. The consequence of this freedom is that they have to face competition and are forced to accept both the successes and failures of their economic activity [47]. Market economy regulation requires freedom of choice together with the resulting autonomy as universal right, i.e. a right to which every individual is entitled. Freedom of choice thus 
requires that legal regulations apply to all individuals equally. Market economy regulation can only guarantee freedom of choice as a universal right if equality before the law also exists as a universal right. This means that freedom of choice and equality before the law are fundamental prerequisites [31] [62]-[64].

Based on these arguments, freedom of choice and equality before the law seem to be means to achieve market economy. However, from our ethical perspective, freedom of choice and equality before the law are not instrumental values but rather intrinsic values [19] [65]. In this view, not freedom of choice and equality before the law are means to achieve market economy but market economy is a means to achieve freedom of choice and equality before the law. Of course, this does not imply that a market economy automatically realizes perfect freedom of choice and equality before the law. In fact, we have to consider that actors differ regarding their resource power [49] so that we have to expect that powerful actors limit the freedom of choice of other actors. Furthermore, our substantiation of market economy goals does not dispute that a concrete market economy regulation also needs to satisfy further objectives. For example, the Basic Constitutional Law of the Federal Republic of Germany (Grundgesetz) provides for the principle of the social state (although it is a matter of contention to what extent). In contrast to freedom of choice and equality before the law, however, these goals form the prerequisite for the constitutionality of market economy regulation rather than the prerequisite for market economy regulation. Therefore, it is debatable if a market economy can apply these social goals, yet this is not the subject of the present paper. The goals freedom of choice and equality before the law may irritate because they do not meet the expectations of "economic" goals like Pareto-efficiency. However, we want to make clear that we cannot justify self-interested acting with Pareto-efficiency, but only with its contribution to freedom of choice and equality before the law.

In fact, we now need to analyze whether freedom of choice and equality before the law as market economy goals support the basic taxation principle of avoiding tax effects. It is necessary to substantiate freedom of choice and equality before the law for this purpose. From a critical rational perspective, we cannot deduce "more geometrico" [18] tax goals from market economy goals. There is also a similar discussion in applied ethics [66]. Rather, we must interpret these goals and for this purpose, we will examine the interpretation of the German Federal Constitutional Court. Under German law and also in other European legal systems, equality before the law is substantiated as equability of taxation. "The principle of equality regulated by Article 3.1 of the Basic Law (Grundgesetz-GG)", states the Federal Constitutional Court, "requires for fiscal law that fiscal status should impose equal burdens on tax payers in legal and factual terms" ([67], p. 94). According to decisions pronounced by the highest court in the country, equability of taxation comprises equal taxation of equal cases or unequal taxation of unequal cases: "The general principle of equality requires that all persons are treated equally before the law. The requirement that follows from this that what is substantially equivalent must be treated equally and what is substantially dissimilar must be treated differently, applies to dissimilar burdens and dissimilar privileges" ([68], p. 416). Belgian [69], Dutch [70], and Spanish tax law [71] is comparable with the German tax law in this respect. To answer the question if cases are equal or unequal, the financial ability to pay functions as a yardstick [72].

Equability of taxation in the legal sense is not identical with horizontal tax equity in tax research, although there are crossovers. Unlike equability of taxation, horizontal tax equity relates much more to individuals than to facts and circumstances. Horizontal tax equity is limited to the equal treatment of individuals in the same situations [73]-[75] and therefore does not include the different treatment of individuals in dissimilar situations as in the legal discourse. Any unequal treatment of unequal cases is actually viewed as vertical equity [73] [75]. The presumed cause of this differentiation is that legal literature primarily focuses on the determination of the tax base and analyses if cases are substantially equivalent or dissimilar. Regarding tax equity, economic literature concentrates more on the problem of the tax rate structure, especially on the question if tax equity requires a progressive or a proportional tax rate function. Nevertheless, as with equability of taxation, a connection between horizontal tax equity and equality before the law is also established [73] [74].

If we take the German Federal Constitutional Court's interpretation of equality before the law as a basis, the question arises how to interpret equal or unequal cases. Equability of taxation requires arguments as to why cases are viewed as equal or unequal with regard to the financial ability to pay [75]. In our opinion, this question has an empirical dimension. According to the view presented here, there is a correlation between in equability of taxation and tax avoidance decisions. Tax avoidance decisions mean certain tax effects which reduce the explicit tax payment burden (in relative terms) [9]. Tax avoidance decisions indicate the following. From the perspective of a tax payer either a case is realized which without tax essentially corresponds to another case for which lower 
tax is payable, or a case is realized which without tax differs from another case and which in relation to this other case attracts a lower level of tax. Tax avoidance decisions are thus an indication that from the point of view of the tax payer, tax rules either treat substantially equivalent cases unequally or they substantially treat dissimilar cases unequally in relative terms [31]. To give an example, the results of empirical studies suggest that without taxes, debt financing by shareholders and equity financing in group structures are equal cases. This means that debt financing is selected if taxation is lower [14]. Tax avoidance decisions would therefore indicate that taxation is not equable. In contrast, ideas of equable taxation and the implementation of it in taxation rules contain the hypothesis that this equable taxation precludes or at least reduces tax avoidance decisions. Therefore, equability of taxation (and thus also equality before the law) supports at least in principle the taxation approach of reducing tax effects by reducing the differences in taxation which cause these tax avoidance decisions. Such a correlation between equability of taxation and tax effects has already been highlighted in tax research literature, although effects usually have a neoclassical basis [15] [16] [76]-[78]; in contrast, with hints of an evolutionary correlation [8]. Otherwise, as already emphasized, economic literature relates to only one aspect of equability of taxation, namely the equal treatment of equal cases [73]-[75].

From a critical rationalist view, it is necessary to support this interpretation of equability of taxation by arguments. One argument is that the German Federal Constitutional Court, the highest court in the country, interprets equality before the law as equability of taxation. Yet, there are also further arguments which confirm that equability of taxation in the sense of reducing tax avoidance is compatible with freedom of choice and equality before the law. Tax avoidance decisions which reduce the absolute tax revenue also generally contradict the aim of market economy regulation to support freedom of choice and equality before the law as universal rights. On the face of it, we can understand tax avoidance decisions as an expression of freedom of choice. However, it is not an expression of freedom of choice as a universal right. Tax avoidance decisions which reduce the absolute tax revenue essentially entail that public goods can either not be financed or else need to be funded by (higher) public debt or by tax increases. Markets and market economy regulation are public goods as well, which also have to be financed via taxes. Tax avoidance decisions thus essentially conflict with the financing of markets, the financing of market economy regulation, and the financing of other public goods, all of which freedom of choice and equality before the law are supposed to secure. "Other public goods" also include the educational system and social security system if we duly consider both a negative view of freedom (defined as the absence of restraints and interference by others) and to the positive freedom to act [65] [79] [80]. If individuals do not have the "freedom to choose between alternative functioning bundles" ([65] p. 279) because of a lack of education or absence of basic financial security, then there is a lack of positive freedom. In terms of content, this displays proximity to the welfare criterion put forward by Christian Schubert, which states that people should be enabled to develop new preferences. This means that there is also a requirement "to invest in education and training at all levels of the economy” ([5], p. 613). Tax avoidance decisions, which essentially jeopardize the financing of these universal rights thus conflict with freedom of choice as a universal right.

Equability of taxation in the sense of reducing tax avoidance can be supported by arguments. In consequence, we now have to examine if this goal is realizable. For this, we need to consider the fact that taxation without tax effects would require taxing the objective of the individual [6]. As in the case of genuine uncertainty no perfectly rational decision criterion exists, a decision-neutral taxation is not realizable [81]. Equability of taxation can therefore only aim at a reduction of tax avoidance decisions by reducing the differences in taxation that cause such decisions. At this point, it is important once more to emphasize that evolutionary tax effects need to be taken into account. In no way should we focus on measuring tax avoidance decisions against a neoclassical ideal that is not realizable, the so-called "Nirvana-approach" [82]. The issue is rather to analyze prevailing law with regard to tax avoidance decisions and to compare it to alternative tax rules within the concept of a "comparative institutions approach” ([30], p. 9226).

Summing up from an evolutionary perspective, we can present arguments for the equability of taxation in the sense of reducing tax avoidance decisions and thus for the avoidance of certain tax effects. Equality of taxation implies the hypothesis that equable taxation decreases tax avoidance decisions. Moreover, an equable taxation contributes to achieving the market economy goals freedom of choice and equality before the law. Based on these results, tax rules which intend to influence decisions conflict with the aims of freedom of choice and equality before the law. Nevertheless, we have to consider that statutorily intended or socially desired goals [45] [74] possibly postulate tax rules which influence financial decisions. We can distinguish such tax rules according to whether they intend tax avoidance decisions or accept tax avoidance decisions as secondary effects. As 
we discussed before, from the perspective of a critical rationalist tax law analysis, we have to ask if these objectives are justified, realizable, and whether the secondary effects accepted in terms of tax avoidance decisions are proportionate.

\section{Summary}

The research question of this paper is: "How can we conceptualize an evolutionary analysis of tax law which refers back to evolutionary hypotheses regarding financial effects of taxation from a critical rationalist perspective?” Taking a critical rationalist view as its starting point, the present paper develops a methodology of an evolutionary tax law analysis. This is characterized by the following aspects.

- From a critical rationalist perspective, we interpret tax rules as means to achieve tax goals. Furthermore, means-end-statements have an ethical and an empirical dimension. The ethical dimension implies that tax goals and tax rules and their secondary effects must be compatible with the aims of market economy regulation. The empirical dimension includes the question if tax goals are realizable and which secondary effects result from tax rules.

- Therefore, hypotheses of tax effects are the theoretical basis of an economic tax law analysis. Starting from evolutionary action hypotheses and an evolutionary market hypothesis, and taking existing theoretical and empirical tax research as a basis, an evolutionary quasi-nomological hypothesis of tax effects is: "If taxation changes the rank order of the relevant decision-making options according to the actors' subjectively rational decision criteria, they decide differently if they take taxes into account than they would if they did not”.

- These hypotheses of tax effects are relevant for economic tax law analysis, either because the tax goal refers directly to tax effects or because of the secondary effects of tax rules. In the first case, we need tax effects hypotheses in order to realize tax goals like "avoiding tax effects" or "inducing tax effects". In the second case, tax effects hypotheses help us to examine which secondary effects we have to accept.

- From an evolutionary point of view, equality before the law and freedom of choice are the contribution of the market economy to the common good. In a critical rationalist view, we cannot deduce "more geometrico" [18] tax goals from these market economy goals. In fact, we have to interpret these goals. Therefore, we adopt the interpretation of the German Federal Constitutional Court that equable taxation requires an equal taxation of equal cases and an unequal taxation of unequal cases. In our opinion, equability of taxation implies the hypothesis that equable taxation decreases tax avoidance decisions and thus the decision-making effects reduce the explicit tax payment burden (in relative terms).

- Given genuine uncertainty, the preclusion of tax avoidance decisions is not realizable. It is only realizable to decrease tax avoidance decisions by reducing the differences in taxation that cause such decisions. For this purpose, it is necessary to analyze prevailing law with regard to tax avoidance decisions and to compare it to alternative tax rules within the concept of a "comparative institutions approach". The focus is not on the reduction of tax avoidance decisions that would occur in a non-realizable ideal world of friction-less perfect markets. In fact, we need evolutionary tax effects hypotheses.

- In our opinion, there are good arguments from an evolutionary point of view that equability of taxation in the sense of avoidance of certain tax effects is an adequate means to achieve freedom of choice and equality before the law. If reduction of tax avoidance decisions is the regular aim, this will permit to intend tax effects as an exceptional aim. Notwithstanding this, tax goals which postulate tax effects have to be justified and realizable and the "secondary effects" must be proportionate.

According to the view expressed here, an evolutionary analysis of tax law is supported by the arguments that suggest a critical rationalist methodology. The evolutionary tax effects hypotheses initially sketched out here can explain tax effects in a scientific manner. This means that the evolutionary tax effects hypotheses explain the correlation between a certain taxation system and a certain (entrepreneurial) action [21]. In addition, the presented theoretical framework is able to explain and integrate the different results of empirical studies on the basis of capital market data and of experimental studies.

Furthermore, the fact that evolutionary tax effects hypotheses are consistently linked with the aims of an evolutionary market order concept supports the evolutionary analysis of tax law outlined here. In a critical rationalist view, it is not sufficient to transform tax effects hypotheses into means-ends-statements. To pursue certain taxation goals in accordance with a critical rationalist methodology actually requires these goals to be compatible with an evolutionary market order concept. This is true in the case of the taxation goal of equability of taxa- 
tion presented here, which is associated with a reduction of differences in taxation caused by tax avoidance decisions.

Based on the methodology of evolutionary tax law analysis, we could examine if tax rules for example the tax rules of company taxation are adequate from an evolutionary point of view. However, the evolutionary analysis of tax law outlined here still leaves numerous aspects undiscussed. Tax effects were, for example, limited to decisions regarding yields. Other topics that would need to be analyzed thus include decisions regarding liquidity, as well as other consequences of taxation, such as implications for distribution or revenues. With regard to the effects on yields, it remains open where the dividing line lies between individuals predominantly following simple heuristics and those actors following differentiated heuristics. We expect that separate acting of individuals deviates from organized acting of individuals in a company and that corporate acting differs yet again [50]. Therefore, it would also be important to substantiate how to explain the acting of companies. If we take methodological individualism as a basis, we have to explain the acting of companies via the acting of the individuals behind such companies. The connectivity to action theories and theories of the firm therefore needs to be established. With regard to the goals of taxation, the question also arises whether they are compatible to social goals which postulate the induction of tax effects and an evolutionary market regulation concept.

This makes it clear that the evolutionary analysis of tax law presented here is an initial outline only. Numerous aspects have not yet been explored. Nevertheless, a critical rationalist methodology carries an obligation to obtain (early) criticism. For this reason, this evolutionary analysis of tax law is presented for debate here.

\section{Acknowledgements}

This paper is part of the research project, Tax law order in a changing society: equability of taxation from the perspective of business taxation. We would like to thank the Fritz Thyssen Foundation for their financial support.

\section{References}

[1] Albert, H. (2000) Kritischer Rationalismus. Mohr Siebeck, Tübingen

[2] Gadenne, V. (2006) Methodological Rules, Rationality, and Truth. In: Cheyne, C., Ed., Rationality and Reality: Conversations with Alan Musgrave, Springer, Netherlands, 97-107. http://dx.doi.org/10.1007/1-4020-4207-8_6

[3] Posner, R.A. (2007) Economic Analysis of Law. 7th Edition, Aspen, New York

[4] Binder, M. (2010) Elements of an Evolutionary Theory of Welfare. Routledge Chapman \& Hall, New York

[5] Schubert, C. (2012) Is Novelty Always a Good Thing? Towards an Evolutionary Welfare Economics. Journal of Evolutionary Economics, 22, 585-619. http://dx.doi.org/10.1007/s00191-011-0257-x

[6] Schneider, D. (2002) Steuerlast und Steuerwirkung. Oldenbourg, Munich. http://dx.doi.org/10.1515/9783486801521

[7] Elschen, R. (1989) Institutionale Oder Personale Besteuerung von Unternehmungsgewinnen? S + W Steuer- und Wirtschaftsverlag, Hamburg.

[8] Elschen, R. (1991) Entscheidungsneutralität, Allokationseffizienz und Besteuerung nach der Leistungsfähigkeit. Steuer und Wirtschaft, 68, 99-115.

[9] Hanlon, M. and Heitzman, S. (2010) A Review of Tax Research. Journal of Accounting and Economics, 50, $127-178$. http://dx.doi.org/10.1016/j.jacceco.2010.09.002

[10] Niemann, R. and Sureth, C. (2013) Sooner or Later?-Paradoxical Investment Effects of Capital Gains Taxation under Simultaneous Investment and Abandonment Flexibility. European Accounting Review, 22, 367-390. http://dx.doi.org/10.1080/09638180.2012.682781

[11] Blaufus, K. and Mantei, B. (2014) Taxes, Risky Investments, and the Simultaneous Choice of Organizational Form and Financing. Journal of Business Economics, 84, 1111-1141. http://dx.doi.org/10.1007/s11573-014-0713-9

[12] Fochmann, M., Kiesewetter, D., Blaufus, K., Hundsdoerfer, J. and Weimann, J. (2010) Tax Perception—An Empirical Survey. Arqus-Working Paper No. 99, Paderborn.

[13] Feld, L.P., Heckemeyer, J.H. and Overesch, M. (2013) Capital Structure Choice and Company Taxation: A Meta Study. Journal of Banking \& Finance, 37, 2850-2866. http://dx.doi.org/10.1016/j.jbankfin.2013.03.017

[14] Schreiber, U. (2012) Besteuerung der Unternehmen, 3. Aufl. Springer Gabler, Wiesbaden.

[15] Wagner, F.W. (1992) Neutralität und Gleichmäßigkeit als ökonomische und rechtliche Kriterien steuerlicher Normkritik. Steuer und Wirtschaft, 69, 2-13. 
[16] Hundsdoerfer, J., Kiesewetter, D. and Sureth, C. (2008) Forschungsergebnisse in der Betriebswirtschaftlichen Steuerlehre-Eine Bestandsaufnahme. Zeitschrift für Betriebswirtschaft, 78, 61-139. http://dx.doi.org/10.1007/s11573-008-0004-4

[17] Schanz, D. and Schanz, S. (2011) Business Taxation and Financial Decisions. Springer, Berlin.

[18] Albert, H. (1985) Treatise on Critical Reason. Princeton University Press, Princeton.

[19] Vanberg, V. (2014) Evolving Preferences and Welfare Economics: The Perspective of Constitutional Political Economy. Jahrbuecher fuer Nationaloekonomie und Statistik, 234, 328-349.

[20] Schreiber, U. (2009) Prinzipien der Unternehmensbesteuerung und die Begrenzung des Zinsabzugs. In: Egner, T., Ed., Steuern und Rechnungslegung, Shaker, Aachen, 419-443.

[21] Opp, K.D. (2014) Methodologie der Sozialwissenschaften, 7. Aufl. Springer Fachmedien Wiesbaden, Wiesbaden.

[22] Popper, K.R. (1968) The Logic of Scientific Discovery. 2nd Edition, Hutchinson \& Co., London.

[23] Friedman, M. (1974) The Methodology of Positive Economics. In: Friedman, M., Ed., Essays in Positive Economics, 8. Aufl, Chicago University Press, Chicago, 3-43.

[24] Caldwell, B.J. (1980) A Critique of Friedman’s Methodological Instrumentalism. Southern Economic Journal, 47, 366-374. http://dx.doi.org/10.2307/1057529

[25] Jacobs, B. (2013) From Optimal Tax Theory to Applied Tax Policy. FinanzArchiv: Public Finance Analysis, 69, 338389. http://dx.doi.org/10.1628/001522113x671155

[26] Scholes, M.S., et al. (2015) Taxes and Business Strategy. 5th Edition, Pearson Prentice Hall, Boston.

[27] Schmidt, R.H. and Terberger, E. (1997) Grundzüge der Investitions- und Finanzierungstheorie, 4. Aufl. Gabler, Wiesbaden.

[28] Vanberg, V. (2002) Rational Choice vs. Program-Based Behavior. Rationality and Society, 14, 7-54.

[29] Vanberg, V. (2004) The Rationality Postulate in Economics: Its Ambiguity, Its Deficiency and Its Evolutionary Alternative. Journal of Economic Methodology, 11, 1-29. http://dx.doi.org/10.1080/1350178042000177987

[30] Vanberg, V. (2001) Markets and the Law. In: Smelser, N. and Baltes, P., Eds., International Encyclopedia of the Social and Behavioral Sciences 14, Elsevier, Amsterdam, 9221-9227. http://dx.doi.org/10.1016/b0-08-043076-7/02897-7

[31] Schmiel, U. (2013) Gleichmäßigkeit der Ertragsbesteuerung-Ein ökonomisch fundiertes Besteuerungsziel? In: Lenel, H.O., Ed., ORDO—Jahrbuch für die Ordnung von Wirtschaft und Gesellschaft, Band 64, Lucius \& Lucius, Stuttgart, 137-162.

[32] Witt, U. (1987) Individualistische Grundlagen der evolutorischen Ökonomik. Mohr Siebeck, Tübingen.

[33] Witt, U. (2009) Novelty and the Bounds of Unknowledge in Economics. The Journal of Economic Methodology, 16, 361-375. http://dx.doi.org/10.1080/13501780903339269

[34] Beckert, J. (1996) What Is Sociological about Economic Sociology? Uncertainty and the Embeddedness of Economic Action. Theory and Society, 25, 803-840. http://dx.doi.org/10.1007/BF00159817

[35] Schmid, M. (2008) Individuelle Entscheidungsrationalität und soziale Einbettung. In: Maurer, A., Ed., Handbuch der Wirtschaftssoziologie, VS Verlag für Sozialwissenschaften, Wiesbaden, 87-108. http://dx.doi.org/10.1007/978-3-531-90905-9_5

[36] Shackle, G.L.S. (1972) Epistemics and Economics. Transaction Publishers, Cambridge.

[37] Watkins, J.W.N. (1978) Freiheit und Entscheidung. Mohr Siebeck, Tübingen.

[38] Schneider, D. (2001) Betriebswirtschaftslehre, Band 4, Geschichte und Methoden der Wirtschaftswissenschaft. Oldenbourg, Munich.

[39] Schneider, D. (2006) Reform der Unternehmensbesteuerung: Niedrigere Steuersätze für zurückbehaltene Gewinne oder höhere Finanzierung aus Abschreibungen? Betriebswirtschaftliche Forschung und Praxis, 59, 262-274.

[40] Buchanan, J.M. and Vanberg, V.J. (1991) The Market as a Creative Process. Economics and Philosophy, 7, 167-186. http://dx.doi.org/10.1017/S0266267100001383

[41] Richter, R. and Furubotn, E.G. (2005) Institutions and Economic Theory. 2nd Edition, The University of Michigan Press, Ann Arbor.

[42] Blaufus, K., Bob, J., Hundsdoerfer, J., Sielaff, C., Kiesewetter, D. and Weimann, J. (2010) Die gefühlte Steuerbelastung des Einkommens, Eine empirische Analyse für Erwerbstätige in Deutschland. Steuer und Wirtschaft, 87, 337 345.

[43] Fochmann, M., Kiesewetter, D. and Sadrieh, A. (2012) Investment Behavior and the Biased Perception of Limited Loss Deduction in Income Taxation. Journal of Economic Behavior \& Organization, 81, 230-242.

[44] Blaufus, K., Bob, J., Hundsdoerfer, J., Sielaff, C., Kiesewetter, D. and Weimann, J. (2013) Decision Heuristics and Tax Perception-An Analysis of a Tax-Cut-Cum-Broadening Policy. Journal of Economic Psychology, 35, 1-16. 
http://dx.doi.org/10.1016/j.joep.2012.12.004

[45] Wegner, G. (2012) Ökonomischer Liberalismus als politische Theorie. Mohr Siebeck, Tübingen.

[46] Smith, A. (1966) An Inquiry into the Nature and Causes of the Wealth of Nations: In Two Volumes. Vol. I, Kelley, New York.

[47] Vanberg, V. (2007) Corporate Social Responsibility and the "Game of Catallaxy": The Perspective of Constitutional Economics. Constitutional Political Economy, 18, 199-222. http://dx.doi.org/10.1007/s10602-007-9022-4

[48] Boettke, P.J. (2012) Living Economics. Yesterday, Today and Tomorrow. The Independent Institute, Oakland.

[49] Pfeffer, J. and Salancik, G.R. (2003) The External Control of Organizations: A Resource Dependence Perspective. Stanford Business Books, Stanford.

[50] Vanberg, V. (1992) Organizations as Constitutional Systems. Constitutional Political Economy, 3, $223-253$. http://dx.doi.org/10.1007/bf02393121

[51] Schmiel, U. (2009) Forschungsziele der Betriebswirtschaftlichen Steuerlehre in der Kritik. Zeitschrift für Betriebswirtschaft, 79, 1193-1214. http://dx.doi.org/10.1007/s11573-009-0310-5

[52] Aspers, P. (2007) Theory, Reality, and Performativity in Markets. American Journal of Economics and Sociology, 66, 379-398. http://dx.doi.org/10.1111/j.1536-7150.2007.00515.x

[53] Kliemt, H. (2011) Ökonomik aus der Teilnehmerperspektive und vom objektiven Standpunkt, Der Konflikt von Marktsoziologie und Entscheidungslogik in anderem Gewande? In: Gadenne, V. and Neck, R., Eds., Philosophie und Wirtschaftswissenschaft, Mohr Siebeck, Tübingen, 117-133.

[54] Meyer, J.W. and Rowan, B. (1977), Institutionalized Organizations: Formal Structure as Myth and Ceremony. American Journal of Sociology, 83, 340-363.

[55] Tversky. A. and Kahneman, D. (1981) The Framing of Decisions and the Psychology of Choice. Science, 211, 453458.

[56] Tversky, A. and Kahneman, D. (1991) Loss Aversion in Riskless Choice: A Reference-Dependent Model. The Quarterly Journal of Economics, 106, 1039-1061.

[57] Kahneman, D. (1992) Reference Points, Anchors, Norms, and Mixed Feelings. Organizational Behavior and Human Decision Processes, 51, 296-312.

[58] Smith, A. (1966) An Inquiry into the Nature and Causes of the Wealth of Nations: In Two Volumes. Vol. II, Kelley, New York.

[59] Sorensen, P.B. (2007) The Theory of Optimal Taxation: What Is the Policy Relevance? International Tax and Public Finance, 14, 383-406. http://dx.doi.org/10.1007/s10797-007-9024-1

[60] Kleinewefers, H. (2008) Einführung in die Wohlfahrtsökonomie. Kohlhammer, Stuttgart.

[61] Langlois, R.N. (1986) Rationality, Institutions, and Explanations. In: Langlois, R.N., Ed., Essays in the New Institutional Economics, Cambridge University Press, Cambridge, 225-255.

[62] Vanberg, V. (2005) Market and State: The Perspective of Constitutional Political Economy. Journal ofInstitutional Economics, 1, 23-49. http://dx.doi.org/10.1017/s1744137405000032

[63] Vanberg, V. (1997) Die normativen Grundlagen von Ordnungspolitik. ORDO: Jahrbuch für die Ordnung von Wirtschaft und Gesellschaft, 48, 707-726.

[64] Vanberg, V. (2011) Liberal Constitutionalism, Constitutional Liberalism and Democracy. Constitutional Political Economy, 22, 1-20. http://dx.doi.org/10.1007/s10602-010-9090-8

[65] Sen, A. (1988) Freedom of Choice. European Economic Review, 32, 269-294. http://dx.doi.org/10.1016/0014-2921(88)90173-0

[66] Beauchamp, T.L. (2003) The Nature of Applied Ethics. In: Frey, R.G. and Wellman, C.H., Eds., A Companion to Applied Ethics, Blackwell Publishing, Malden, 1-16.

[67] Federal Constitutional Court (2005) Decision of 09.03.2004 (2 BvL 17/02). Entscheidungen des Bundesverfassungsgerichts, 110, 94-141. English version: http://www.bundesverfassungsgericht.de/SharedDocs/Entscheidungen/EN/2004/03/ls20040309_2bvl001702en.html

[68] Federal Constitutional Court (2010) Decision of 21.07.2010 (1 BvR 611, 2464/07). Entscheidungen des Bundesverfassungsgerichts, 126, 400-433. English Version:

http://www.bundesverfassungsgericht.de/SharedDocs/Entscheidungen/EN/2010/07/rs20100721_1bvr061107en.html

[69] van Crombruegge, S. (1999) Belgium. In: Meussen, G., Ed., The Principle of Equality in European Taxation, Springer Netherland, London, 51-73.

[70] Happé, R. (1999) The Netherlands. In: Meussen, G., Ed., The Principle of Equality in European Taxation, Springer Netherlands, London, 125-155. 
[71] Rosembuj, T. (1999) Spain. In: Meussen, G., Ed., The Principle of Equality in European Taxation, Springer Netherlands, London, 157-163.

[72] Vogel, K. and Waldhoff, C. (1999) Germany. In: Meussen, G., Ed., The Principle of Equality in European Taxation, Springer Netherland, London, 89-114.

[73] Musgrave, R. (1990) Horizontal Equity, Once More. National Tax Journal, 43, 113-122.

[74] Elkins, D. (2006) Horizontal Equity as a Principle of Tax Theory. Yale Law and Policy Review, 24, 43-90.

[75] Repetti, J. and Ring, D. (2012) Horizontal Equity Revisited. Florida Tax Review, 13, 135-155.

[76] Wagner, F.W. (2003) Die real existierende Einkommensteuer ist eine konsumorientierte Besteuerung. In: Ahlheim, M., Wenzel, H.D. and Wiegard, W., Eds., Steuerpolitik-Von der Theorie zur Praxis: Festschrift für Manfred Rose, Springer, Berlin, 369-390. http://dx.doi.org/10.1007/978-3-642-55887-0_18

[77] Sureth, C. (2006) Steuerreformen und Übergangsprobleme bei Beteiligungsinvestitionen. Deutscher Universitäts-Verlag, GWV Fachverlage GmbH, Wiesbaden.

[78] Hemmerich, K. and Kiesewetter, D. (2014) Entscheidungsneutrale, gleichmäßige und rechtssichere Einkommensbesteuerung unter Unsicherheit. Zeitschrift für Betriebswirtschaftliche Forschung, 66, 98-119.

[79] Berlin, I. (2002) Introduction. In: Berlin, I., Ed., Liberty, Oxford University Press, Oxford, 3-54.

[80] Berlin, I. (2002) Two Concepts of Liberty. In: Berlin, I., Ed., Liberty, Oxford University Press, Oxford, 166-217.

[81] Schneider, D. (2000) Mängel in der ökonomischen Begründung einer Steuerfreiheit für Kapitaleinkünfte. Steuer und Wirtschaft, 77, 421-430.

[82] Demsetz, H. (1969) Information and Efficiency: Another Viewpoint. Journal of Law and Economics, 12, 1-22. http://dx.doi.org/10.1086/466657 